\title{
A TESTETLEN ESZKÖZÖK JELENTŐSÉGE A VÁLLALAT MÜKÖDÉSÉBEN, PÉNZÜGYI TELJESÍTMÉNYÉBEN ÉS PIACI ÉRTÉKELÉSÉBEN
}

Az elmúlt két évtizedben jelentôsen növekedett a testetlen eszközök (intangible assets) szerepe a vállalatok múkködésében, pénzügyi teljesítményében és versenyképességében. A vállalatok mind nagyobb mértékben alapozzák tevékenységüket a testetlen vagyon elemeire, miközben a dologi eszközök jelentősége mérséklődik. A vállalatspecifikus testetlen eszközök a tudás és az információ köré összpontosulnak, spill-over hatással rendelkeznek, és felhalmozódásuk sajátos. A testetlen eszközök egyediségének és az általuk várhatóan generált jövốbeni pénzáramsor nehéz elôrejelezhetôségének következtében értékelésük számottevố bizonytalanságot és szubjektivitást rejt magában; a befektetók azonban rendszerint magas piaci értéket társítanak hozzájuk, minthogy a piaci siker meghatározóinak tekintik óket. A vállalatok bensố és piaci értékének eltérését elemzó elméletek egy csoportja szerint pedig a testetlen eszközöknek szignifikáns hatása van a két érték különbségére. A szerzố tanulmányában rámutat a testetlen eszközök vállalati múköoésben és versenyképességben betöltött szerepére, a dologi vagyon elemeitôl eltérố tulajdonságaira, értékelésére és a vállalatok piaci értékére gyakorolt hatására.

Kulcsszavak: testetlen eszközök, versenyképesség, bizonytalanság, érték, értékelés

A testetlen eszköz fogalmát az IAS pontosan meghatározza: „fizikai állomány nélküli, azonosítható, nem pénzügyi eszköz" (Salines, 2009: p. 2). Az IAS szerint akkor tekinthető egy eszköz azonosíthatónak, ha az vagy szerződésszerú, vagy más jogosultságból származik, vagy ha elkülöníthetô - ami azt jelenti, hogy önállóan vagy más, vele kapcsolatban álló eszközökkel együtt értékesíthetô. Az IAS alapján, továbbá akkor és csak akkor minősíthető egy eszköz testetlennek, ha feltételezhetô, hogy az általa várhatóan generált jövôbeni hozam a gazdasági egységhez fog áramlani, és az eszközköltség pedig megbízható módon mérhető (Salines, 2009). Pénzügyi megközelítésben a testetlen eszközöket az IAS-nél általában tágabban értelmezik, különösen az értékelés szempontjából, hiszen egy vállalat, illetve részvényeinek piaci értékét olyan tényezốk is befolyásolják, mint például $a$ vállalati hírnév, az ügyfélelégedettség, az ellátási lánc rugalmassága, az alkalmazottak tudása és képességei, vagy a munka- folyamatok szervezésének hatékonysága. Ezek viszont számviteli értelemben nem tartoznak a testetlen eszközök közé. A testetlen eszközök csoportjába sorolhatjuk még továbbá, például $a K+F$-t, a szabadalmakat, $a$ márkákat, a szoftvereket, a vásárlói hüséget és a beszállitói kapcsolatokat is. A továbbiakban a testetlen eszközök csoportját tágan értelmezzük; minthogy nem csupán az IAS meghatározása által azonosíthatónak tekinthetô nem fizikai eszközök képezik egy vállalat jövőbeni hozamának forrását.

A testetlen eszközök értelmezése, jelentősége és csoportjai

A testetlen eszközök többféleképpen csoportosíthatók. Azért érdemes áttekinteni többfajta kategorizálást, mert a különböző szempontok alapján történő rendszerezés felhívja a figyelmet a nem fizikai jellegú eszközök tulajdonságaira. Elsôként tekintsük a számviteli megkö- 
zelítésen alapuló felosztásokat. Avery (1942) alapján Vaughan (1972) a testetlen eszközöket kezdetben biztos (határozott) és bizonytalan (határozatlan) élettartamúakra osztotta. Az elóbbibe különböző szerződések, egyezmények, jogok tartoznak - amelyek amortizáció tárgyát képezik, az utóbbiba a márka, a személyzet, a hírnév, továbbá például a technológiai know-how és a piaci elfogadás (Wilson, 1986). Napjainkban a vállalati múködés és a versenyképesség szempontjából ez utóbbiak jelentôsége a nagyobb. Így a testetlen javak többsége esetében a bizonytalan élettartam következtében nem lehet előre meghatározni, hogy meddig fognak várhatóan a jövóben pénzáramot generálni. Ez egyben azt is jelenti, hogy nehezen becsülhetố meg elóre, meddig lesz versenyképes egy márka a piacon, illetve hogy egy biotechnológiai $\mathrm{K}+\mathrm{F}$ eredményeképpen létrejövő innovációt mikor fog felváltani egy újabb. Az IFRS a testetlen eszközök öt nagy csoportját különbözteti meg: a marketinggel összefüggóket (pl. védjegy, internet domainnév), a szerződésszerúeket (pl. haszonbérleti szerződés, franchise szerződés), a technológiaalapúakat (pl. szoftver, adatbázis), az ügyfelekre vonatkozókat (pl. ügyfél kapcsolatok és szerződések) és a múvészeti jellegúeket (Salines, 2009; Global Intangible Tracker, 2006).

A vállalati múködés és a piaci stratégia szempontjából relevánsabbnak és kifejezóbbnek találom Haigh (2003) és Gerzema - Lebar (2008) - egymáshoz nagyon hasonló - csoportosítását. Haigh (2003) a testetlen eszközök négy nagy kategóriáját határozza meg:

- tudás: pl. szabadalmak, szoftverek, sajátos knowhow mint a gyártási és múködési irányelvek, termékkutatás, információs adatbázisok,

- üzleti folyamatok: az üzleti, vállalati folyamatok megszervezésének egyedi módjai, beleértve például a flexibilis gyártási technológiákat és az ellátási lánc kialakítását,

- piaci pozíció: pl. kiskereskedelmi szerződések, disztribúciós jogok, licencek, termelési és importkvóták,

- márka és a hozzá kapcsolódó testetlen eszközök: pl. védjegy, domainnevek, designjogok, csomagolás, goodwill.

Gerzema - Lebar (2008) rendszerezése annyiban tér el ettól, hogy az üzleti folyamatok helyett az üzleti rendszer kifejezést használja, és fordított sorrendben sorolja fel az eszközcsoportokat, a márkát teszi az elsố helyre. Haigh (2003) kiemeli, hogy iparáganként eltéró a testetlen eszközö̈k négy típusának a relatív jelentósége. A gyógyszeriparban a tudásnak, a kiskereskedelemben az üzleti folyamatok összehangoltságának, hatékonyságának vagy rugalmasságának van meghatározó jelentősége. A légi közlekedésben pedig a piaci pozíció rendkívül fontos és a versenyképesség meghatározója. Számos fogyasztási jószág esetében, például a luxus termékeknél vagy a tartós fogyasztási javaknál, a márka a legjelentősebb testetlen eszköz, alapvetően ez határozza meg a vásárlási döntést. A technológiára és kutatásra épüló ágazatokban is fontos szerepet játszanak azonban a márkák, minthogy ezek az eszközök tudják a vállalat technológiai kompetenciáit piaci sikerré alakítani.

A testetlen eszközök, mint a fenntartható versenyelóny forrásai testetlen eróforrás elnevezéssel is szerepelnek a szakirodalomban. Hall (1993) publikációja alapján Fernández - Montez - Vázquez (2000) a testetlen eróforrások két nagy csoportját különbözteti meg aszerint, hogy azok embertól függóek, avagy nem. Az embertôl függó testetlen eróforrások legjobb példája a humán tốke, vagyis az alkalmazottak által elsajátított tudás, tapasztalat, illetve az ô képességeik és személyes kapcsolataik. Az embertől független testetlen eróforrások három kategóriába sorolhatók: szervezeti tốke, technológiai tóke és kapcsolati tóke. A szervezeti tóke foglalja magában például az adminisztratív múveleteket, a vállalati kultúrát és a stratégiai szövetségeket. A technológiai tốke a termék és a termelési folyamatok innovációjához kapcsolódó tudást tartalmazza. A kapcsolati tôke pedig a piaci tényezókból - úgymint a hírnév, a márkanév, a fogyasztói húség - származó lehetôséget jelenti (Heiens - Leach - McGrath, 2007).

Eróforrás-alapú megközelítést alkalmaz Wyatt (2008) is a testetlen eszközök csoportosításához. A testetlen eszközök hat kategóriáját határozza meg, és ezeket három vállalati erôforrástípusba sorolja:

- technológiai eróforrások, 1. $\mathrm{K}+\mathrm{F}$ kiadások és a kapcsolódó szellemi tulajdon,

- humán erôforrások, 2. humán tốke,

- termelési eróforrások, 3. reklám, márkák és a kapcsolódó szellemi tulajdon,

4. vásárlói húség,

5. versenyelöny,

6 . goodwill.

Ez a hat kategória átfedi, és nem pedig kizárja egymást (Wyatt, 2008). A testetlen eszközök eróforrás-típusú rendszerezése hatékony lehet a vállalat erósségeinek és gyengeségeinek feltárása, a vállalati folyamatok szervezése és a piaci stratégia kialakítása szempontjából is. Könnyen átláthatóvá teszi, hogy a vállalat 
milyen vagyonelemekre támaszkodhat, illetve, hogy a vállalatnak milyen eszközökre érdemes alapoznia versenyelónyét.

A vállalatok mintegy két évtized óta egyre nagyobb mértékben építik múködésüket a testetlen tốkére, a hagyományos dologi eszközök pedig mind kevesebb szerephez jutnak (Danthine - Jin, 2007). Ennek során a testetlen eszközök, valamint azok integrációi napjainkra a vállalati növekedés és a versenyképesség kulcsfontosságú tényezóivé váltak (Olsen - Halliwell, 2007). Azok a vállalatok képesek a legmagasabb értéket létrehozni érdekhordozóik számára, amelyek eredményesen tudják a testetlen eszközök egymáshoz kapcsolódását megteremteni az üzleti folyamatok kialakítása során (Walters - Halliday, 2005). A testetlen eszközök vállalati múködésre és teljesítményre gyakorolt szignifikáns hatásának következményeként a pénzügyi piacokon $a$ befektetók értékelése során is lényegesen nagyobb súlya lett a testetlen vagyonnak, mint a dologinak. Meglátásom szerint a testetlen eszközök vállalatspecifikus, egyedi jellege az, amelyre a vállalatok alapozzák vagy alapozhatják a stratégiáikat és piaci sikerüket. A testetlen vagyon létrehozásához azonban beruházásra van szükség.

Annak ellenére, hogy a versenyelóny mind nagyobb mértékben tudható be a testetlen eszközök fejlesztésének és integrációjának, kevés vállalat ismeri csak valóban el e speciális eszközök meghatározó szerepét. Ez pedig nem az optimális stratégia megalkotásához vezet (Heberden, 2006). Heberden (2006) felhívja a figyelmet arra, hogy nagyon lényeges felismerni a testetlen eszközök értékláncban való kulcsfontosságú és összetett pozícióját. A testetlen eszközök értékláncban való szerepének világossá tétele elősegíti egy jobb vállalati stratégia megalkotását és a testetlen eszközök eredményesebb, hatékonyabb menedzselését. Véleményem szerint a porteri értékláncot tekintve tulajdonképpen bármely elsődleges és támogató tevékenységnek képezheti alapját vagy meghatározó elemét egy, vagy akár több testetlen eszköz. Ehhez kapcsolódóan a Porter (2006) által meghatározott általános versenystratégiák közül a termékmegkülönböztetésnek van relevanciája a múködésüket testetlen eszközökre alapozó vállalatok esetében. A termékmegkülönböztetés számos lehetốséget rejt magában, főbb formái, mint a márkaépítés, a $\mathrm{K}+\mathrm{F}$ eredményeképpen létrejövő technológia, vagy a rugalmas ellátási lánc középpontjában azonban a testetlen eszközök állnak. Ezek egyedivé alakításával képes a vállalat kitúnni versenytársai közül; amelynek következményeképpen a tôzsdei befektetók is magasan értékelik a vállalat részvényeit. Porter (2006) kiemeli továbbá, hogy célszerú a vállalatnak több tényezô alapján is megkülönböztetnie magát. Azon vállalatok esetében, ahol a múködésben meghatározó szerepe van a testetlen eszközöknek, gyakran meg is figyelhető az egyedi jellegú testetlen eszközök egymáshoz kapcsolódása. Például a K+F eredményeképpen létrejövő termékinnováció piacra vitele során fontos szerepe van a márkának is.

\section{A testetlen eszközök sajátos jellemzői}

A testetlen eszközök számos olyan tulajdonsággal rendelkeznek, amelyek megkülönböztetik óket a dologi eszközöktól, és így azoktól eltéró döntéshozatalt, menedzselést és értékelést kívánnak meg. Másrészról a testetlen eszközöknek olyan sajátosságaik vannak, amelyeket a vállalati döntéshozóknak fontos figyelembe venniük a stratégiaalkotás során. Az alábbiakban a testetlen eszközök meghatározó tulajdonságait tekintem át.

A testetlen eszközök többnyire a tudás és az információ köré összpontosulnak (Heiens - Leach - McGrath, 2007). Úgy vélem, minthogy ebból következóen spillover hatásuk van, igen nehezen ragadhatók meg ezek az eszközök, vagyis nehezen határozható meg közvetlenül a vállalati tevékenységekre és teljesítményre gyakorolt befolyásuk. Nehéz megbecsülni például, hogy egy, az ügyfelek körében végzett megkérdezéses vizsgálat eredményeképpen rendelkezésre álló információk, amelyek nagy segítséget nyújthatnak az új termék fejlesztése, valamint a márka menedzselése és promóciótervezése során, mennyiben befolyásolják a jövőbeni hozamok alakulását. Basu - Waymire (2008) hasonlóképpen ötleteket és tudást ért testetlen javakon, és kiemeli, hogy általában egyediek. Meglátásom szerint a testetlen eszközök létrehozásához szükséges ötletek és tudás, valamint azok sajátos jellemzói között közvetlen kapcsolat van. Egy a versenytársakétól könnyen megkülönböztethetô, nagyban eltérő, feltúnő és hatékony reklámnak például valamilyen különleges ötleten kell alapulnia, az információtechnológiai és a biotechnológiai innovációk létrehozásához magas szakmai tudásra és jó problémafelismerô képességre van szükség, versenyelőny pedig csak akkor érhetố el és tartható fenn, ha a vállalat valamifajta egyedülálló előnyt, értéket tud nyújtani fogyasztói számára - azonban ennek megvalósításához is hozzáértésre, jó elgondolásokra van szükség. Danthine - Jin (2007) is vállalatspecifikusnak tartja a beruházás eredményeképpen létrejövő testetlen vagyont. Basu Waymire (2008) ehhez kapcsolódóan továbbá rámutat arra, hogy a testetlen eszközök jelentősége a vállalat számára az, hogy vagyont képezzenek korábban ismeretlen lehetőségek feltárásával, az ötleteken, tudáson alapuló testetlen eszközök értékes javakká, szolgáltatá- 
sokká konvertálhatók közvetlenül vagy közvetve. Ennek egyik legjobb példája, hogy a humán tôkét felhasználó kutatás-fejlesztés eredményeképpen termék- vagy technológiai innováció jöhet létre. A testetlen javak továbbá Danthine - Jin (2007) szerint nincsenek kereskedelmi forgalomban és nem tulajdoníthatók el; ez véleményem szerint nem minden eszközre érvényes, minthogy például a márkák adásvétel tárgyát képezhetik, és a disztribúciós jogok, valamint a magas szaktudással rendelkezók, de a vállalaton kívül dolgozó szakemberek is megszerezhetốk.

A testetlen tớke dologi eszközöktól eltérố jellegû́ akkumulációjára hívja fel a figyelmet Danthine - Jin (2007). Amíg a dologi vagyon felhalmozása eszközról eszközre történik a beruházási költségek felmerülésével, addig a testetlen tốke egy olyan folyamat eredménye, amelynek során rendkívüli áttörések lehetnek, ez pedig az értékében gyors növekedéshez vezethet - föként, ha a K+F-et tekintjük. Fontos dologra mutat rá a szerzőpáros, én azonban más szempontból tartom sajátságosnak a testetlen tóke akkumulációját. A beruházások eredményeképpen létrejövó testetlen eszközök adott idópontbeli értékét nagymértékben meghatározzák az idốpont elótti, a testetlen eszköz létrehozásához, menedzseléséhez kapcsolódó folyamatok, illetve azok eredménye; és ez számottevó hatást gyakorol az érdekhordozók döntéseire. A márkák esetében például mind a fogyasztói megítélést, mind a befektetői értékelést jelentősen befolyásolja a márka eddigi „élete”, a fejlôdési irányvonal, az imázs, a közvetített értékek, a minôség. A humán tốke értéke az elsajátított tudáson, a fejlesztett képességeken, a megszerzett tapasztalatokon, a motiváción, a teammunkában való együttmúködési készségen alapul. A legjobb példa azonban a vállalati hírnév, amely a vállalat eddigi múködésén, tevékenységein nyugszik. Így tehát amíg a dologi eszközöknél, mint a gépek, berendezések, nyersanyagok, földterület, rendszerint az adott idôpontbeli állapot vagy érték határozza meg a velük kapcsolatos döntést, a testetlen eszközöknél a hozzájuk kapcsolódó múltbeli tevékenységeknek, illetve azok eredményének is releváns hatása van. A testetlen vagyon felhalmozása azonban nem feltétlenül jelent mindig bövülést, vagyis értéknövekedési folyamatot. Gondoljuk arra, hogy a fogyasztók termékekkel való elégedettsége, a márkák pénzügyi értéke, a stratégiai szövetségek érvényesülése vagy a vállalati hírnév nem mindig emelkedik, erősödik, hanem egyegy helytelen vállalati döntés vagy a versenytársak sikeres lépései következtében viszonylag rövid időn belül csökkenhet. A vállalaton belüli, alkalmazottak közötti konfliktusok vagy egy-egy nagy tudású és elhivatott szakember vállalattól való távozása is negatí- van hat. Fontos kiemelni azt is, hogy egy-egy testetlen eszköz értéke nagyon gyorsan változhat különbözó vállalati döntések és piaci mozgások eredményeképpen, a dologi eszközök értéke ezzel szemben hosszú távon is csak relatíve kismértékben, és ami ennél sokkal fontosabb, hogy jól előre jelezhetố módon módosul (ha csak valamilyen rendkívüli esemény be nem következik), és esetükben alapvetóen a fizikai állapotuk, illetve az amortizáció mértéke határozza meg az értéküket.

A testetlen eszközökbe történó beruházásokat a heterogenitás és a standardizáltság hiánya jellemzi. Ez mind az input, mind az output oldalra érvényes. Amíg a gépek, berendezések múködtetéséhez szükséges inputigények és ráfordítások viszonylag jól előre jelezhetők és kalkulálhatók, addig a testetlen eszközök esetében sokkal nagyobb a bizonytalanság. A K+F esetében nagyon sok előre nem látható dolog van, amelynek következtében szükség lehet e tevékenységekre fordított összeg növelésére, a reklám- és márkaberuházásokra jelentős hatással van a vállalat pénzügyi helyzete és a piaci verseny, a vállalaton kívülról vásárolt testetlen javak (pl. tanácsadás) ellenértéke pedig általában igen széles intervallumban mozoghat. Tekintve a másik oldalt, a testetlen eszközökbe történő beruházások outputja nehezen kontrollálható és nehezen határozható meg elöre (Wyatt, 2008 hiv. Webster, 1999), ennek egyik legjobb példája az ügyfél-elégedettség - nagyon bizonytalan az, hogyan fogadják a potenciális fogyasztók az újonnan kifejlesztett terméket vagy márkát. A testetlen eszközökkel kapcsolatos ráfordítások tehát kevésbé biztosak a dologi eszközökhöz képest. A testetlen eszközökbe irányuló beruházások ugyanakkor segítenek megkülönböztetni a vállalat értékteremtő folyamatait a rutinmúveletektôl. Ez egyúttal azt is jelenti, hogy a testetlen eszközöket a versenytársak nehezen tudják másolni, valamint hogy a testetlen eszközökkel csökkenthetố a vállalati múködésre hatást gyakorló ellenốrizhetetlen tényezók száma (Wyatt, 2008 hiv. Webster, 1999).

A dologi eszközökhöz viszonyítva jelentôsen nagyobb a bizonytalanság a várható jövóbeni hozam generálásának idótartamát és nagyságát tekintve a testetlen eszközök esetében (Choi - Kwon - Lobo, 2000). Amíg viszonylag jól megbecsülhető, hogy egy termelőeszköz hány évig múködtethető, vagy hány termék előállítására lesz alkalmas, addig lényegesen nehezebb meghatározni azt, hogy például a fogyasztók meddig maradnak majd húségesek egy márkához, a beszállítói kapcsolatok meddig lesznek fenntarthatók, vagy egy reklámkampány milyen hosszú ideig és mekkora többlethozamot képes generálni. Kumar (2005) kiemeli, hogy míg a testetlen eszközök hozamrátájának szórá- 
sa viszonylag kicsi lehet, addig értékének szórása igen nagy. A dologi eszközökhöz képest nehezebb mérni a testetlen eszközöket, minthogy ez utóbbiak értékének becslése attól függ, hogy mekkora vagyoni értéket hoznak létre a vállalat számára (Bond et al., 2000). A testetlen eszközök értékelése bonyolult és bizonytalanságot magában rejtó folyamat (Foster - Fletcher - Stout, 2003). Az is gátolja a pontos értékelést, hogy a testetlen eszközök rendszerint közvetve, egy dologi eszközön keresztül, vagy egy másik testetlen eszközzel együtt generálnak hozamot (Basu - Waymire, 2008). Az elsôre jó példa a márkának a termékhez való kapcsolódása, a másodikra pedig a humán tókének és a K+F-nek az összefüggése.

\section{A testetlen eszközök értéke és a vállalat piaci értékére gyakorolt hatása}

A befektetốk számára kevés hasznos információt nyújt a mérleg a testetlen eszközökról. A testetlen eszközökbe történó beruházást költségként könyvelik el, a reklámot például értékesítési költségnek, a tréninget pedig adminisztratív költségnek (Danthine - Jin, 2007). A testetleneszköz-ráfordítások azonban többnyire beruházások, minthogy a jövóbeli hozamgenerálás érdekében keletkeznek, a $\mathrm{K}+\mathrm{F}$ beruházások például közvetlenül az innováció létrehozásához kapcsolódnak, a reklámok pedig a piaci részesedés növeléséhez (Wyatt, 2008). A nemzetközi számviteli standardok csak a megvásárolt testetlen eszközök mérlegbe való rögzítését teszik lehetôvé, az adott vállalat által kifejlesztetteket viszont nem engedik meg (Foster - Fletcher - Stout, 2003). Roberts (2001) szerint ez a legfóbb oka annak, hogy a mérlegek nem tükrözik a valódi értéket. Egyes szakemberek szerint viszont a vállalaton belül kifejlesztett testetlen eszközöket is meg kellene jeleníteni fair piaci értéken a mérlegben, ugyanúgy, ahogy a vállalaton kívülról megszerzetteket (Foster - Fletcher - Stout, 2003). Choi - Kwon - Lobo (2000) vizsgálatának eredményei rámutatnak arra, hogy a piac pozitívan értékeli a beszámolóban szereplő testetlen eszközöket.

A vállalatok testetlen eszközökbe történó beruházásának nagysága többféleképpen becsülhetố. Nakamura (2001) három különböző aspektust használ. Az egyik mód számviteli megközelítésú, a K+F-be, a márkafejlesztésbe, a szoftverbe és a többi testetlen eszközbe történő beruházások elszámolását veszi alapul. A másik mód a „kreatív dolgozóknak”, vagyis a testetlen eszközöket létrehozóknak kifizetett bérek, fizetések kalkulálása. Egy harmadik lehetôség pedig a vállalatok múködési árrésében bekövetkező változások vizsgálata; Nakamura (2001) szerint a bruttó árrés növekedése elsősorban a testetlen eszközökból származó értékteremtésnek tudható be, például az internetalapú ellátási láncok költségmegtakarításainak. Ez a háromféle megközelítés azonban kissé eltérô eredményeket ad (Lev, 2003).

A testetlen eszközök összértékét, vagy másképpen a vállalat eszmei értékét gyakran a vállalat teljes piaci értéke és a dologi eszközök értéke közti különbségként határozzák meg. A testetlen eszközök értékének ily módon történô megállapítása azt feltételezi, hogy a dologi eszközök által termelt hozam egyenlő a tókeköltséggel. A tốkeköltséget meghaladó bármekkora mértékú hozam pedig a testetlen eszközök által generált hozam (Salines, 2009). Az egyes testetlen eszközök egyenkénti értékelése is szükségessé válhat valamilyen technikai vagy kereskedelmi célból. Gyakran azonban nehéz azonosítani a vállalat által birtokolt vagy megszerzett testetlen vagyont (Olsen - Halliwell, 2007). Ennek oka az, hogy sokszor nehezen elkülöníthetốk a vállalat más eszközeitól, vagy időnként nehezen felismerhetók, mert szorosan hozzákapcsolódnak egyes üzleti folyamatokhoz. Ebból következóen viszont az értékelés folyamata számottevó bizonytalanságot foglal magában.

A testetlen eszközök közül a márkák kapják a legnagyobb figyelmet az értékelés szempontjából, a fogyasztói és a pénzügyi értékeléssel egyaránt foglalkoznak. A márkaértékelés pénzügyi módszerei között megtalálhatók (teljesen) objektív alapokon nyugvó, racionális technikák és a fogyasztói értékítéletet magukban foglaló eljárások is, minden esetben azonban az értékelés céljának legmegfelelóbb módszert kell választani (Kovács, 2008). A pénzügyi értékelési technikákat rendszerint négy nagy kategóriába sorolják: költségalapú, piaci alapú, jövedelemalapú és szabályszerú megközelítések (Cravens - Guilding, 1999). Fernández (2002) kiemeli, hogy a márkaértékelés folyamata segít a márka értékét befolyásoló tényezốk felismerésében és meghatározásában, valamint bóvíti a márkáról a vállalat rendelkezésére álló információkat.

Bármely testetlen eszköz értékelése során Olsen Halliwell (2007) szerint két dologra fontos figyelni. Az egyik az, hogy egy testetlen eszköz értékelésekor többféle megközelítést célszerü alkalmazni. A testetlen eszközök értékelési folyamata ugyanis szubjektivitást rejt magában, ez azonban különböző módszerek használatával kiküszöbölhető és egy hiteles érték megállapításához vezethet. Egy általam végzett empirikus márkaelemzés során összehasonlítottam a legkonzervatívabb és az egyik legkifinomultabb pénzügyi márkaértékelési módszert, hogy rávilágítsak a különböző technikák alapján történő kalkulációkban lévő eltérésekre. Vizsgálatom fố konklúziója, hogy a költségalapú és az 
Interbrand értékelési módszerek nagyon eltérô eredményeket adhatnak (Kovács megjelenés alatt). Másrészról az is releváns Olsen - Halliwell (2007) alapján, hogy szükséges felismerni azokat a tényezóket, amelyek hatást gyakorolhatnak a testetlen eszközök értékére, ilyen komponensek lehetnek például a tókével kapcsolatos költségek, a funkcionális és a gazdasági avulás, a termékértékesítési ciklus vagy a szinergialehetôségek is.

A testetlen eszközök értékelésével kapcsolatban Kumar (2005: p. 78.) végül egy „ördögi körre” hívja fel a figyelmet: „A testetlen eszközökkel kapcsolatos információk nincsenek feltárva, minthogy a testetlen eszközök fair értékei nem határozhatók meg anélkül, és a testetlen eszközök fair értékei nem határozhatók meg anélkül, hogy ne készítenénk gazdasági kutatást a dologi és testetlen inputokkal történő dinamikus termelési struktúráról. Ilyen gazdasági kutatás viszont nem történhet, mert a szükséges információkat nem tartalmazza a pénzügyi kimutatás."

A könyv szerinti vagy bensố érték és a piaci érték kapcsolatát és eltérését vizsgáló elméletek egy csoportja szerint a testetlen eszközöknek van releváns hatása a két érték közti különbségre. Ez a - befektetói várakozásokat és piaci mechanizmusokat középpontba állító nézeteknél újabb - megközelítésmód azon alapul, hogy a vállalatok piaci értéke azért jelentósen magasabb, vagy gyakran többszöröse is a könyv szerinti vagy bensố értéknek, mert a - mérlegben általában nem rögzített, vagy nem megfelelő értékkel szereplő - testetlen eszközök mind nagyobb mértékben befolyásolják a vállalatok múködését, pénzügyi teljesítményét és versenyképességét; és ez számottevôen megemelte értéküket. A dologi eszközök ezzel egyidejúleg egyre kisebb arányát adják a vállalatok teljes piaci értékének.

A testetlen eszközök közül kiemelt jelentősége van a márkáknak. Több kutatás rámutat arra, hogy a márkák a vállalatok legértékesebb eszközei (Gerzema - Lebar, 2008; Gerzema et al., 2007; Raggio - Leone, 2009) és egyben a vállalati eszközök közül a legkevésbé ingadozó értékforrások is (Best Global Brands 2008; 2009). A márkák piaci értékének növekedése és a befektetôk irracionális márkatúlértékelése kapcsán Gerzema - Lebar (2008) felhívja a figyelmet a márkabuborék létrejöttére (1. ábra). Arról van szó, hogy a tókepiac magasabbra értékeli a márkákat, mint azok a fogyasztók, akik megvásárolják óket, és ennek következtében a márkák tartósan emelkedő befektetői értékelése márkabuborékot hoz létre. A fogyasztó számára az észlelt hasznosság és az ár közötti különbség teremt értéket. A tókepiacok azonban márkák ezreit olyan magasra értékelik (fenntarthatatlan szintekre), hogy a nekik betudható jövedelempotenciál nagymértékben meghaladja a fogyasztók számára nyúj- tott értéküket; ennek eredményeképpen pedig márkabuborék jön létre. Tovább fokozza e hatást, hogy amíg a tókepiacok a márkákat egyre magasabbra értékelik, addig a fogyasztók márkákkal szembeni attitúdje lényegesen romlik. Empirikus vizsgálatok támasztják alá, hogy a fogyasztók márkatudatossága, márkaértékelése, márkaminőség-észlelése és márkák iránti bizalma jelentősen csökken. Ez az anomália, vagyis az érdekhordozók két nagy csoportjának értékelése között növekvố rés a márkabuborék kipukkadásához vezethet.

1. ábra

A márkabuborék lényege

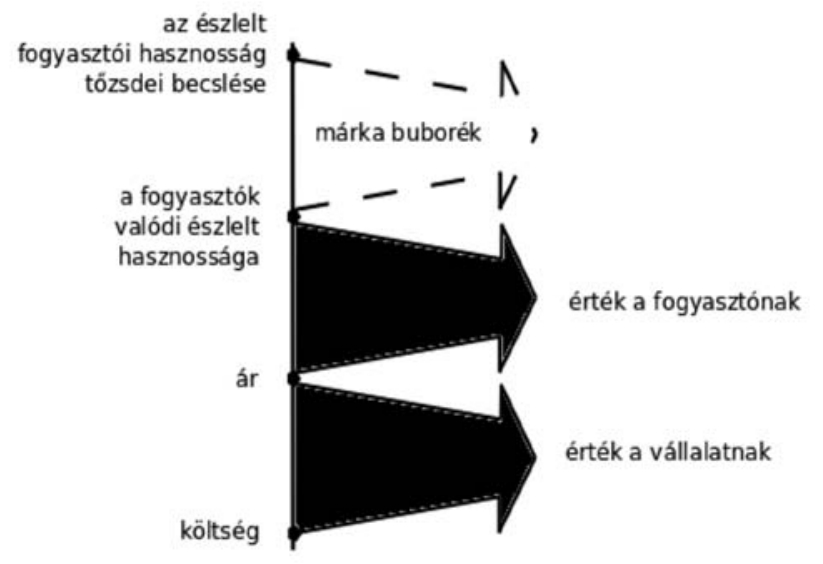

Forrás: Gerzema - Lebar (2008: 7. o.)

A testetlen eszközöknek a vállalat piaci értékére gyakorolt hatását számos kutató vizsgálta. Hirschey (1982) eredményei azt mutatják, hogy pozitív, szignifikáns hatása van a reklám és $\mathrm{K}+\mathrm{F}$ ráfordításoknak a piaci értékre. Joshi - Hanssens (2010) vizsgálatai szerint is összefüggésben állnak egymással a reklámráfordítások és a vállalat piaci értéke. Amir Harris - Venuti (1993), Chauvin - Hirschey (1994) és McCarthy - Schneider (1995) a goodwill és a vállalat piaci értéke között talált pozitív, szignifikáns kapcsolatot. A márkaérték, az ügyfél-elégedettség mértéke és a $\mathrm{K}+\mathrm{F}$ beruházás is jelentős hatással van a vállalat piaci értékére (Srinivasan - Hanssens, 2009; Gupta Zeithaml, 2006; Barth et al., 1998). Mindez azt jelenti tehát, hogy ha a vállalatok jelentôs összegeket fordítanak K+F-re, reklámra, jó a vállalat hírneve, magas a márka fogyasztói és/vagy pénzügyi értéke, akkor a befektetók hajlandók viszonylag magas árat fizetni a vállalati részvényekért. Az erôs márkákkal továbbá nemcsak magasabb részvényhozam érhető el, de alacsonyabb kockázat is (Madden - Fehle - Fournier, 2006). Aksoy et al. (2008) kutatási eredményei arra mutatnak rá, hogy a részvényesi értéket létrehozó ügyfél-elégedettséget a tőzsde kezdetben alulértékeli, hosszú távon viszont alkalmazkodik a piac a pozitív 
információkhoz. Yeung - Ennew (2000) kutatása szerint az ügyfél-elégedettségnek szignifikáns hatása van a részvények árára, a részvényhozamokat viszont nem feltétlenül befolyásolja. A szerzópáros ezt azzal indokolja, hogy az ügyfél-elégedettség fontos szerepet játszik a befektetôi döntésekben - minthogy jelentôsen befolyásolja egy vállalat pénzügyi teljesítményét, és így a részvényárakban is tükröződik a hatása, a részvényhozam viszont egy olyan összetett mutató, amelynél a múltbeli tényezók relevánsabbak. Empirikus kutatások igazolták továbbá azt is, hogy a befektetôk a részvény értékelésekor figyelembe veszik a márkák fogyasztói és/vagy pénzügyi értékét is (Srinivasan Hanssens, 2009). A márkák fogyasztói megítélésére a befektetốk - expliciten vagy impliciten - nagyon érzékenyek, és az ezzel kapcsolatos információkat felhasználják a vállalatok várható jövớbeli profitabilitásának becslésekor.

Érdekes dologra hívja fel a figyelmet Howrey (2002) száz befektetô körében végzett vizsgálata. A megkérdezettek többsége, mintegy $89 \%$-a, a vállalat testetlen eszközeit jelentős tényezőnek tekinti beruházási döntése során. Ennek ellenére csupán egyharmaduk elemzi és értékeli mindig vagy rendszerint formálisan a vállalat testetlen eszközeinek értékét egy potenciális beruházás mérlegelésekor. Úgy gondolom, ez arra mutat rá, hogy a befektetók fontosnak tartják a testetlen eszközöket a vállalati múködés, pénzügyi teljesitmény és versenyképesség szempontjából, az értékelésükhöz azonban nagymértékú szubjektivitás társul, minthogy általában nem alkalmaznak pénzügyi értékelési módszereket, amelyekkel becsülhető az, hogy az eszköz a jövốben várhatóan mekkora pénzáramot fog generálni, illetve, hogy mekkora a bensô vagy piaci értéke. A Deutsche Bank felmérése szerint olyan tényezók akadályozzák a testetlen eszközök értékelési módszereinek alkalmazását, mint például az értékelési módszerek hitelességének hiánya, jártasságában való hiány, a vállalatok által a testetlen vagyon értékelésére alkalmazott módszerek sokfélesége, vagy a testetlen eszközök összehasonlíthatóságának lehetetlensége (Salinas, 2009 hiv. Hofmann, 2005).

Egy kutatás során Bond et al. (2000) azt kívánta feltárni, hogy a részvénypiaci árak és a dologi tốkeállomány értéke közti arány növekedése betudható-e a testetlen vagyon profit generálásban való növekvő szerepének. Az elemzés konklúziója, hogy azonosítható ugyan a testetlen beruházások korlátozott szerepe, nem bizonyítható azonban az, hogy ez a tényező önmagában képes magyarázni a vállalatok tôzsdei értékében bekövetkező jelentős növekedést. Az eredmények a részvényárak alakulását illetően jelentős anomáliákra mu- tatnak rá. A Brand Finance vizsgálata szerint viszont a jelentősebb részvényindexek tókeértékének 60-75\%-át a testetlen eszközök teszik ki (Salines, 2009: p. 23. hiv. Haigh - Chng, 2005).

A fentiekben már ismertetett Danthine - Jin (2007) akkumulációs nézet alapján a testetlen tốkét nem determinisztikus, hanem sztochasztikus akkumulációs folyamat jellemzi, és ez a szerzôpáros vizsgálatai szerint számottevô mértékben növeli a részvényhozamok és a P/E arány volatilitását. Másrészról pedig a testetlen eszközök sajátos akkumulációja magyarázatul szolgálhat a részvényhozamokban, a részvényárakban és a vállalati értékekben megfigyelhetố jelentốs ingadozásokhoz. A testetlen eszközök felhalmozódásának nyomon követése így rendkívül fontos a részvényhozamok, a vállalatértékelés és a P/E arány vizsgálata szempontjából.

\section{Összegzés}

A testetlen eszközök napjainkra a vállalati múködés, pénzügyi teljesítmény és versenyképesség meghatározóivá váltak. A testetlen eszközök legfontosabb jellemzói, hogy valamilyen formában a tudáshoz, az információhoz kapcsolódnak, egyediek, a dologi eszközöktôl eltérố a felhalmozódásuk, és hogy nagymértékú a bizonytalanság az általuk várhatóan generált jövóbeni hozam időtartamát és nagyságát tekintve. Mindez a fizikai eszközöktôl különböző menedzselést, döntéshozatalt és értékelést tesz szükségessé. Annak ellenére, hogy nehéz meghatározni a testetlen eszközök értékét, az értékláncban való kulcsfontosságú szerepük vitathatatlan, különösen, ha több testetlen vagyoni elem összekapcsolódása valósul meg, ezért is fontos beruházásként tekinteni a testetlen eszközökkel kapcsolatos ráfordításokat. A testetlen eszközöknek szignifikáns hatása van a vállalatok piaci értékére, amely azt tükrözi, hogy a befektetốk mindinkább felismerik a vállalati múködésben és versenyképességben érvényesülő jelentőségüket. Ennek hatására a vállalatok piaci értékében ma már gyakran a testetlen vagyon aránya a nagyobb.

\section{Felhasznált irodalom}

Aksoy, L. - Cooil, B. - Groening, C. - Keiningham, T.L. - Yalçin, A. (2008): The Long-Term Stock Market Valuation of Customer Satisfaction. Journal of Marketing, Vol. 72, No. 4, p. 105-122.

Amir, A. - Harris, T.S. - Venuti, E.K. (1993): A Comparison of the Value-Relevance of US versus Non-US GAAP Accounting Measures Using Form 20-F Reconciliations. Journal of Accounting Research, Vol. 31, No. 3, p. 230 264. 
Avery, H.G. (1942): Accounting for Intangible Assets. The Accounting Review, Vol. 17, No. 4, p. 354-363.

Barth, M.E. - Clement, M.B. - Foster, G. - Kasznik, R. (1998): Brand Values and Capital Market Valuation. Review of Accounting Studies, Vol. 3, No. 1-2, p. 41-68.

Basu, S. - Waymire, G. (2008): Has the Importance of Intangibles Really Grown? And if so, Why? Accounting and Business Research, Vol. 38, No. 3, p. 171-190.

Best Global Brands 2008 (2009): Creating and Managing Brand Value. Interbrand honlapja www.interbrand.com Letöltés ideje: 2009. 01. 31.

Bond, S.R. - Cummins, J.G. - Eberly, J. - Shiller, R.J. (2000): The Stock Market and Investment in the New Economy: Some Tangible Facts and Intangible Fictions. Brookings Papers on Economic Activity, Vol. 31, No. 1, p. 61-124.

Chauvin, K.W. - Hirschey, M. (1994): Goodwill, Profitability, and the Market Value of the Firm. Journal of Accounting and Public Policy, Vol. 13, No. 2, p. 159-180.

Choi, W.W. - Kwon, S.S. - Lobo, G.J. (2000): Market Valuation of Intangible Assets. Journal of Business Research, Vol. 49, No. 1, p. 35-45.

Cravens, K.S. - Guilding, C. (1999): Strategic Brand Valuation: A Cross-Functional Perspective. Business Horizons, Vol. 42, No. 4, p. 53-62.

Danthine, J.-P. - Jin, X. (2007): Intangible Capital, Corporate Valuation and Asset Pricing. Economic Theory, Vol. 32, No. 1, p. 157-177.

Fernández, E. - Montez, J.M. - Vázquez, C.J. (2000): Typology and Strategic Analysis of Intangible Resources: A Resource-Based Approach. Technovation, Vol. 20, No. 2, p. 81-92.

Fernández, P. (2002): Valuation of Brands and Intellectual Capital. Research Paper No. 456. Univeristy of Navarra, Barcelona. IESE honlapja: www.iese.edu Letöltés ideje: 2007. 03. 03.

Foster, B.P. - Fletcher, R. - Stout, W.D. (2003): Valuing Intangible Assets. The CPA Journal, Vol. 73, No. 10, p. 50-54.

Gerzema, J. - Lebar, E. - Sussman, M. - Gaikowski, J. (2007): Energy: Igniting Brands to Drive Enterprise Value. International Journal of Market Research, Vol. 49, No. 1, p. 25-45.

Gerzema, J. - Lebar, E. (2008): The Brand Bubble: the Looming Crisis in Brand Value and How to Avoid It. Jossey-Bass: A Wiley imprint., San Fransisco, CA

Global Intangible Tracker 2006 (GIT ${ }^{\mathrm{TM}}$ 2006): An Annual Review of the World's Intangible Value. Brand Finance honlapja: www.brandfinance.com Letöltés ideje: 2007. 02. 20.

Gupta, S. - Zeithaml, V. (2006): Customer Metrics and Their Impact on Financial Performance. Marketing Science, Vol. 25, No. 6, p. 687-717.

Haigh, D. (2003): Brand Valuation: What It Means and Why It Matters. In: Brands in the Boardroom. IAM supplement No. 1, p. 18-21. Brand Finance honlapja: www.brandfinance.com Letöltés ideje: 2007. 02. 20.
Haigh, D. - Chng, D. (2005): Singapore Firms' Intangible Assets are Grossly Undervalued: A Study of Intangible Value by Brand Finance. Nanyang Business Review, Vol. 4, No. 1, Brand Finance honlapja: www.brandfinance. com Letöltés ideje: 2010. 01. 01.

Hall, R. (1993): A Framework Linking Intangible Resources and Capabilities to Sustainable Competitive Advantage. Strategic Management Journal, Vol. 14, No. 8, p. 607-618.

Heberden, T. (2006): Intangible Asset Valuation, Resource Management and Strategic Planning: Leveraging the Value of Intangible Resources. Brand Finance honlapja: www.brandfinance.com Letöltés ideje: 2009. 12. 11.

Heiens, R.A. - Leach, R.T. - McGrath, L.C. (2007): The Contribution of Intangible Assets and Expenditures to Shareholder Value. Journal of Strategic Marketing, Vol. 15, No. 2/3, p. 149-159.

Hirschey, M. (1982): Intangible Capital Aspects of Advertising and R\&D Expenditures. The Journal of Industrial Economics, Vol. 30, No. 4, p. 375-390.

Hofmann, J. (2005): Value intangibles! Intangible capital can and must be valued - owners and valuers alike will benefit. 19 October 2005, Deutsche Bank Research, Frankfurt am Main

Howrey (2002): A Survey of Investor Attitudes on IP. Howrey Europe honlapja: www.howrey.com Letöltés ideje: 2010. 01. 31.

Joshi, A. - Hanssens, D.M. (2010): The Direct and Indirect Effects of Advertising Spending on Firm Value. Journal of Marketing, Vol. 74, No. 1, p. 20-33.

Kovács K. (2008): A márkák pénzügyi értékelésének módszerei. Vezetéstudomány, No. 39, No. 3, p. 9-19.

Kovács $K$ : A márkák pénzügyi értékelése és a vállalat pénzügyi teljesítményére gyakorolt hatása. Controllingtrendek, megjelenés alatt

Kumar, T.K. (2005): Disclosure Norms for Intangible Assets: Suggestions for Improving the Valuation of Intangibles. IIMB Management Review, Vol. 17, No. 1, p. 71-78.

Lev, B. (2003): Remarks on the Measurement, Valuation, and Reporting of Intangible Assets. FRBNY Economic Policy Review, September, p. 17-22.

Madden, T.J. - Fehle, F. - Fournier, S. (2006): Brands Matter: An Empirical Demonstration of the Creation of Shareholder Value Through Branding. Journal of the Academy of Marketing Science, Vol. 34, No. 2, p. 224-235.

McCarthy, M.G. - Schneider, D.K. (1995): Market Perception of Goodwill: Some Empirical Evidence. Accounting and Business Research, Vol. 26, No. 1, p. 69-81.

Nakamura, L. (2001): What is the U.S. Gross Investment in Intangibles? (At Least) One Trillion Dollars a Year! Federal Reserve Bank of Philadelphia Working Paper, No. 01-15.

Olsen, M.G. - Halliwell, M. (2007): Intangible Value: Delineating Between Shades of Gray. Journal of Accountancy, Vol. 203, No. 5, p. 66-72. 
Porter, M.E. (2006): Versenystratégia. Akadémiai Kiadó, Budapest

Raggio, R.D. - Leone, R.P. (2009): Chasing Brand Value: Fully Leveraging Brand Equity to Maximize Brand Value. Brand Management, Vol. 16, No. 4, p. 248-263.

Roberts (2001): The Reporting Gap: Earnings and Other Financials No Longer Suffice as Measures of Corporate Health. Electronic Business, Vol. 19, No. 3.

Salines, G. (2009): The International Brand Valuation Manual: A Complete Overview and Analysis of Brand Valuation Techniques, Methodologies and Applications. Wiley \& Sons, Chichester

Srinivasan, S. - Hanssens, D.M. (2009): Marketing and Firm Value: Metrics, Methods, Findings, and Future Directions. Journal of Marketing Research, Vol. 46, No. 3, p. 293-312.

Vaughan, J.L. (1972): Give Intangible Assets Useful Life. Harvard Business Review, Vol. 50, No. 5, p. 127-132.
Walters, D. - Halliday, M. (2005): Marketing and Financial Management: New Economy - New Interface. Palgrave Macmillan, New York

Webster, E. (1999): The Economics of Intangible Investment. Edward Elgar, Cheltenham

Wilson, R.M.S. (1986): Accounting for Marketing Assets. European Journal of Marketing, Vol. 20, No. 1, p. 5174.

Wyatt, A. (2008): What Financial and Non-Financial Information on Intangibles Is Value-Relevant? A Review of the Evidence. Accounting and Business Research, Vol. 38, No. 3, p. 217-256.

Yeung, M.C.H. - Ennew, C.T. (2000): From Customer Satisfaction to Profitability. Journal of Strategic Marketing, Vol. 8, No. 4, p. 313-326.

Cikk beérkezett: 2010. 2. hó

Lektori vélemény alapján véglegesítve: 2010. 3. hó

\section{E SZÁMUNK SZERZÖI}

Dr. Fülöp Gyula, egyetemi tanár, Miskolci Egyetem; Pelczné dr. Gáll Ildikó, egyetemi docens, Miskolci Tudományegyetem; Dr. Simon Judit, egyetemi docens, Budapesti Corvinus Egyetem; Dr. Mandják Tibor, egyetemi docens, Budapesti Corvinus egyetem; Dr. Szalkai Zsuzsanna, tudományos munkatárs, Budapesti Corvinus Egyetem, egyetemi docens, Budapesti Múszaki és Gazdaságtudományi Egyetem; Tóth László, egyetemi adjunktus, Budapesti Corvinus Egyetem; Dr. Kovács Kármen, PhD, egyetemi adjunktus, Pécsi Tudományegyetem; Bódi-Schubert Anikó, PhD-hallgató, Budapesti Corvinus Egyetem; Dr. Dobrai Katalin PhD, egyetemi docens, Pécsi Tudományegyetem; Dr. Krisztián Béla, egyetemi docens, Pécsi Tudományegyetem 